\title{
ジャンプトレーニングが思春期後期にある 男子生徒の疾走能力に与える影響
}

岩竹淳 1),2）北田 耕司 ${ }^{2)}$ 川原 繁樹 ${ }^{2)}$ 図子 浩二 ${ }^{3)}$

Jun Iwatake ${ }^{1,2}$, Koji Kitada ${ }^{2}$, Shigeki Kawahara ${ }^{2}$ and Koji Zushi': The influence of jump training on the sprinting ability in late pubertal boy students. Japan J. Phys. Educ. Hlth. Sport Sci., 53: 353-362, September, 2008.

\begin{abstract}
The purpose of this study was to clarify whether sprinting and jumping performance in late pubertal male students would be improved by jump training and other types of training. The subjects were classified into four groups; a jump training group (hurdle jump, skipping and bounding), a resistance training group (leg lunge, single leg squat and half squat), a complex training group, and a control group. Training was continued once a week for eight weeks. As a result, the rebound jump power [power $\left.=\left(g^{2} \cdot t_{f} \cdot t_{f}\right)\left(4 \cdot t_{c}\right)\right]$, the distance covered by a standing five jump, and that covered by a standing triple jump increased in the jump training group, whereas the rebound jump contact time decreased. Moreover, the rebound jump power, the height of the counter-movement jump and the distance of the standing triple jump increased in the complex training group. In the resistance training group and the control group, each measured item showed no change. The 50-m mean sprinting velocity increased significantly in the jump training and the complex training groups. Moreover, the sprinting velocity at 10-m intervals between the 30-40-m and 40-50-m sprints increased significantly in the jump training group, as did the maximum sprinting velocity. The improvement of leg output power over a short time was considered to make a large contribution to maximum sprinting performance. The information presented is considered beneficial for improving physical education class and sports performance.
\end{abstract}

Key words : $50 \mathrm{~m}$ sprinting, plyometrics, stretch-shortening cycle exercise, jumping ability キーワード : $50 \mathrm{~m}$ 走, プライオメトリックス, 伸張一短縮サイクル運動, ジャンプ力

\section{I 緒言}

ヒトの疾走能力は形態的な発達に強い影響を受 けるため（斉藤・伊藤, 1995), 思春期後期の年代 に身長の発達速度が急激に減少する（マリーナ・ブ シャール, 1995） と, 疾走能力の発達も停滞の傾向 を示す (加藤, 2004). そのため, 思春期後期にあ る生徒を対象として, 疾走能力を改善する体育授
業を推進していくためには，形態的な要因に頼ら ずに筋機能を改善するトレーニングを導入する必 要があると考えられる。

疾走能力を改善するためには，陸上競技の短距 離選手が用いるような，短時間の高強度運動を反 復することで無酸素性エネルギー供給能を高める 疾走トレーニングがある。しかし，体育授業にお いて，非競技者の生徒を対象に過剩な強度の運動 を反復させることは，体調を損なうという健康管
1）鹿屋体育大学大学院体育学研究科博士後期課程

干 891-2393 鹿児島県鹿屋市白水町 1 番地

2) 石川工業高等専門学校一般教育科保健体育 干 929-0392 石川県河北郡津幡町北中条夕 1

3）鹿屋体育大学体育学部スポーツパフォーマンス系

干 891-2393 鹿児島県鹿屋市白水町 1 番地
1. Graduate School of Physical Education Doctor's Course, National Institute Fitness and Sports in Kanoya Shiromizu, Kanoya, Kagoshima 891-2393

2. Department of Health and Physical Education, Ishikawa National College of Technology

Kitachujo, Tsubata, Kahoku, Ishikawa 929-0392

3. Department of Sports Performance, National Institute Fitness and Sports in Kanoya

Shiromizu, Kanoya, Kagoshima 891-2393

Corresponding author iwatake@ishikawa-nct.ac.jp 
理上の問題も危惧されるため実用的ではない。一 方, 近年の疾走能力を改善させるためのトレーニ ングに関する研究では, リバウンドジャンプやド ロップジャンプのパフォーマンス（跳躍高, 発揮 パワー, stiffnessなど）と疾走能力との間に有意 な相関関係が認められることや（Mero et al., 1981; Bosco et al., 1983; Chelly and Denis, 2001; Bret et al., 2002; 岩竹ほか, 2001, 2002), ジャンプトレーニン グプログラム（ドロップジャンプ，バウンディン グおよびスキップ）を 10 週間の体育授業で実践し た結果, 非競技者の思春期前期にある児童の疾走 能力が改善することが報告されている (Kotzamanidis, 2006). ジャンプトレーニングは, 自 重負荷を利用した運動の反復であるため障害の危 険が少なく(Bobbert, 1990), 八ムストリングスの筋 力が向上することや (Hewett et al., 1995), 股関節内 転筋群の予備緊張が大きくなることで膝関節が安 定するため, スポーツ障害の予防に効果的とされ ている (Chimera et al., 2004). これらのことから, 疾走能力を改善するためにジャンプトレーニング を実施することは, 短時間で高強度運動を反復す るようなトレーニングに比較して安全性が高く, 思春期後期にある生徒を対象とした体育授業にお いても導入可能と考えられる。

しかし，これまでに行なわれてきたジャンプト レーニングが疾走能力に与える影響に関する研究 は，思春期前期の年代を対象としたものであり， 現在のところ思春期後期にある生徒を対象とした 報告は見当たらない，思春期前期の年代では筋力 や瞬発力の増加が著しいのに対して, 思春期後期 の年代におけるそれは緩やかになることから（桜 木, 2000), 思春期後期にある生徒は先行研究
(Kotzamanidis, 2006) で対象とされた被験者とは発 育段階として異なる。そのため，体育授業におけ るジャンプトレーニングが思春期後期にある生徒 の疾走能力に与える影響を検討することは, 中等 教育における体育授業を構築していく上で意義の あるものと考えられる.

そこで本研究では，思春期後期にある生徒のう ち男子を対象として，体育授業におけるジャンプ トレーニングが局面別疾走能力に与える影響につ いて, 各種のジャンプ力や脚筋力の適応を手がか りに検討することにした。 また，ジャンプトレー ニングの効果を筋力トレーニング, 複合トレーニ ングおよびコントロール条件と比較することによ り，ジャンプトレーニングの特徴的な効果につい ても明らかにする。

\section{II 方法}

\section{1. 被験者}

被験者は，これまで計画的にジャンプトレーニ ングや筋力トレーニングを実施した経験のない, 高等専門学校の一年次に在籍する男子生徒 97 名 (年齢 $15.6 \pm 0.3$ 歳, 身長 $168.8 \pm 6.0 \mathrm{~cm}$ および体重 $59.3 \pm 9.3 \mathrm{~kg})$ とし， ジャンプトレーニング群，筋 カトレーニング群, 複合トレーニング群およびコ ントロール群に分類した。各トレーニング群にお ける年齢，身長および体重は Table 1 にまとめて示 した。な押，本研究におけるトレーニング群の分 類は，体育授業を受けるクラス単位としたことか ら，トレーニング前における疾走速度やジャンプ 力等の初期値を均等にすることはできなかった.

被験者には, 予め本研究の主旨と内容について

Table 1 Means and standard deviations for subject characteristics of the each training group

\begin{tabular}{lccrc}
\hline & $\begin{array}{c}\text { Jump } \\
\text { training } \\
(\mathrm{n}=20)\end{array}$ & $\begin{array}{c}\text { Resistance } \\
\text { training } \\
(\mathrm{n}=21)\end{array}$ & $\begin{array}{c}\text { Complex } \\
\text { training } \\
(\mathrm{n}=27)\end{array}$ & $\begin{array}{c}\text { Control } \\
(\mathrm{n}=29)\end{array}$ \\
\hline Age (yr) & $15.6 \pm 0.4$ & $15.6 \pm 0.3$ & $15.6 \pm 0.3$ & $15.5 \pm 0.3$ \\
Body height $(\mathrm{cm})$ & $166.9 \pm 4.8$ & $168.7 \pm 7.3$ & $169.4 \pm 5.7$ & $169.6 \pm 5.9$ \\
Body mass $(\mathrm{kg})$ & $59.8 \pm 12.2$ & $57.2 \pm 8.3$ & $59.0 \pm 8.0$ & $60.7 \pm 9.1$ \\
\hline
\end{tabular}


説明し，実験参加への同意を得るとともに，デー 夕の発表についての了承を得た。なお，本研究は， 所属機関における倫理委員会の承諾を得た後, 研 究実施機関における研究遂行の許可を得た上で実 施した。

\section{2. トレーニング}

本研究では, ジャンプトレーニング, 筋力ト レーニングおよび複合トレーニングを週 1 回の頻 度で 8 週間連続して実施した。各トレーニングプ ログラムの回数およびセット数は, Table 2 に示し た. 被験者には, 体育授業以外に特別な運動を行 なわないよう指示をした。

\section{1）ジャンプトレーニング}

体育授業に扔けるトレーニングは, 本研究に示 していない女子生徒を含めると, 常時 40 名以上の 対象者を指導することになる。 そのため, 被験者 全員が同時に運動を実施した場合, 験者は被験者 の動作を十分に観察できないことや, 被験者の集 中力欠如による授業の混乱を招くことになる。 そ こで，ジャンプトレーニング群においては，験者 がトレーニング指導を行ないやすいよう, 被験者 を二列縦隊に整列させて一人ずつ交互に運動させ ることが可能なハードルジャンプ，スキップおよ びバウンディングの三種目を採用した。

ハードルジャンプは，池田・淵元 (2005) と同様に $90 \mathrm{~cm}$ の間隔で並べられた 6 台のハードルを両脚で 跳び越えていくものとした. トレーニングは, 被 験者の安全を考慮して左右対称に並べたハードル の間にゴムチューブを張ったものを用いた．高さ
は $40 \mathrm{~cm}$ および $60 \mathrm{~cm}$ の二種類を設定し，被験者 のジャンプ力に応じてトレーニングする高さを選 択させた. 6 回の連続したハードルジャンプを 1 セットとし，6セット行なわせた．スキップは，数 歩の助走をつけた後に, 距離の獲得を意識させな がら左右交互に 10 回の連続したジャンプを 1 セッ トとし，6セット行なわせた。 バウンディングは, 立位の状態から左右交互に 10 回の連続したジャン プを 1 セットとし，6セット行なわせた。これら のトレーニングでは，できるだけ接地時間を短く して膝関節を曲げすぎないように意識させた。

2）筋力トレーニング

筋力トレーニング群には, レッグランジ, シン グル・レッグ・スクワットおよびスクワットの三 種目を行なわせた。 このうち, レッグランジはジャ ンプトレーニングと同様に, 被験者を二列縦隊に 整列させてトレーニングを実施させた。レッグラ ンジは自重負荷とし，両脚の接地時に股関節を伸 展した側の膝が地面に触れることを条件とした。 左右交互に 10 回の連続した運動を 1 セットとし, 6 セット行なわせた.

シングル・レッグ・スクワットおよびスクワッ 卜は，被験者を三人一組にしてパートナーに膝関 節角度を確認してもらうよう指示をした。シング ル・レッグ・スクワットは自重負荷とし，膝関節角 度 90 度まで屈曲することを条件とした，姿勢バラ ンスの保持を目的に補助者を利用することは認め るが, 脚伸展運動の助力としてはならないことを 指示した. 片脚 10 回の連続した下肢の屈伸を 1 セットとし，左右の脚それぞれに 6 セット行なわ

Table 2 Each training programs and number of jumps per session

\begin{tabular}{|c|c|c|c|c|c|c|}
\hline \multirow{2}{*}{ Exercise } & \multicolumn{2}{|c|}{ Jump training } & \multicolumn{2}{|c|}{ Resistance training } & \multicolumn{2}{|c|}{ Complex training } \\
\hline & Reps & Series & Reps & Series & Reps & Series \\
\hline Hurdle jump & 6 & 6 & & & 6 & 3 \\
\hline Skipping & 10 & 6 & & & 10 & 3 \\
\hline Bounding & 10 & 6 & & & 10 & 3 \\
\hline Leg lunge & & & 10 & 6 & 10 & 3 \\
\hline Single leg squat & & & 10 & 6 & 10 & 3 \\
\hline Squat & & & 10 & 6 & 10 & 3 \\
\hline
\end{tabular}


せた。スクワットは，体重の近似した被験者を負 荷として背負い, 膝関節角度 90 度まで屈曲するこ とを条件とした。両脚 10 回の連続した下肢の屈伸 を 1 セットとし，6セット行なわせた.

筋力トレーニングのプログラムは，いずれも反 動を利用せずに験者の合図に合わせて 2 秒に 1 回 の頻度で運動を反復するよう指示をした。

3）複合トレーニング

複合トレーニング群は, ジャンプトレーニング および筋力トレーニングをそれぞれ 3 セットずつ 行なわせた。

\section{3. 疾走能力の評価}

被験者には，十分なウォーミングアップの後に， 陸上競技場直線走路に扔いて $50 \mathrm{~m}$ の全力疾走を行 わせた. クラウチングスタートによるスタートダッ シュでは，個人毎のスタート技術が記録に大きく 影響すると考え，被験者の自由なタイミングでス タートさせるスタンディングスタートを用いた。 疾走記録の測定は, スタートから $10 \mathrm{~m}$ 間隔に磁気 発生装置（ACTYE 社製，マグネットバー）を設置 し, 腰部に磁気センサー（ACTYE 社製，パーソナ ルタイマー) を装着した被験者が側面を通過する ことで記録を読み取るシステムを用いた。疾走能 力の評価は, ほぼ無風の条件下で実施することと し，風の影響がないように配慮した。

本研究では，疾走距離を疾走記録で除すること により, $50 \mathrm{~m}$ 平均疾走速度, $10 \mathrm{~m}$ 区間毎の疾走速 度を算出した。 また， $10 \mathrm{~m}$ 区間毎の疾走速度の増 加分 $(\Delta \mathrm{v})$ を区間毎に要した時間 $(\Delta \mathrm{t})$ で除すること により加速度を算出した。 $10 \mathrm{~m}$ 区間毎の加速度お よび疾走速度の最大值は，それぞれ最大加速度抒 よび最大疾走速度とした。本研究で算出した各項 目を疾走能力の評価指標として用いた。

\section{4. 各種ジャンプカの評価}

本研究では, 垂直跳の跳躍高, リバウンドジャ ンプの跳躍高, 接地時間およびパワー (Bosco et al., 1983), 立幅跳, 立三段跳および立五段跳の跳躍距 離を評価した。いずれの測定も体育館フロアで実 施した。垂直跳抢よびリバウンドジャンプの跳躍
高は，マットスイッチ（DKH 社製，マルチジャン プテスタ) を用いて滞空時間 (flight time: $t_{f}$ )を測定 し, 次式 $〔 \mathrm{~h}=1 / 8 \cdot \mathrm{g} \cdot \mathrm{t}_{\mathrm{f}}^{2} 〕$ により算出した. リバウ ンドジャンプのパワーは, 滞空時間 $\left(\mathrm{t}_{\mathrm{f}}\right)$ と接地時 間 (contact time: $\mathrm{t}_{\mathrm{c}}$ ) を測定し, 次式〔power $=\left(\mathrm{g}^{2} \cdot \mathrm{t}_{\mathrm{f}}\right.$. $\left.\left.\mathrm{t}_{\mathrm{t}}\right) /\left(4 \cdot \mathrm{t}_{\mathrm{c}}\right)\right]$ により算出した $\left(\mathrm{g}=9.81 \mathrm{~m} \cdot \mathrm{s}^{-2}, \mathrm{t}_{\mathrm{t}}=\mathrm{t}_{\mathrm{f}}+\mathrm{t}_{\mathrm{t}}\right)$. リバウンドジャンプは，腰に手を当てた 6 回の連 続垂直跳とし，パワーの最大值を採用した。立幅 跳の跳躍距離は，両脚を揃えた立位姿勢の爪先を 基準として, 着地時の踵までの跳躍距離をメ ジャーで測定した。これらの評価指標は, 両脚同 時のジャンプ力と定義した。 また, 立幅跳と同じ 方法で立五段跳および立三段跳の跳躍距離を測定 し，これらを片脚交互のジャンプ力と定義した。

\section{5. 最大脚伸展筋力の評価}

本研究では, スクワット姿勢による最大脚伸展 筋力（以下，脚筋力）を測定した。スクワットの 膝関節角度は Wilson et al. (1993) の報告に従い，疾 走またはジャンプ時に観察される $135^{\circ}$ とた。 ま た, Young et al. $(1995,1999)$ と同様に，スクワット ラックに固定したシャフトに対して急激に力を発 揮させず，ゆっくりと徐々に力を出すことで最大 筋力を発揮するよう指示をした．脚筋力の測定は 5 秒間とし，フォースプレート（KISTLER 社製, クワトロジャンプ）を用いて測定した地面反力の 最大值を採用した。

\section{6. 統計処理}

本研究で用いた数值は, 全て平均士標準偏差で 示した。トレーニング前後における各測定值の比 較には，F 検定 (F-test) により二群の等分散性を確 認した後にスチューデントの t 検定 (Student's t-test) を実施した。いずれの統計処理も有意性は危険率 $5 \%$ 未満とした.

\section{III 結果}

Fig. 1 は, $50 \mathrm{~m}$ 平均疾走速度, 最大加速度およ び最大疾走速度をトレーニング前後で比較したも のである. $50 \mathrm{~m}$ 平均疾走速度は, ジャンプトレー 

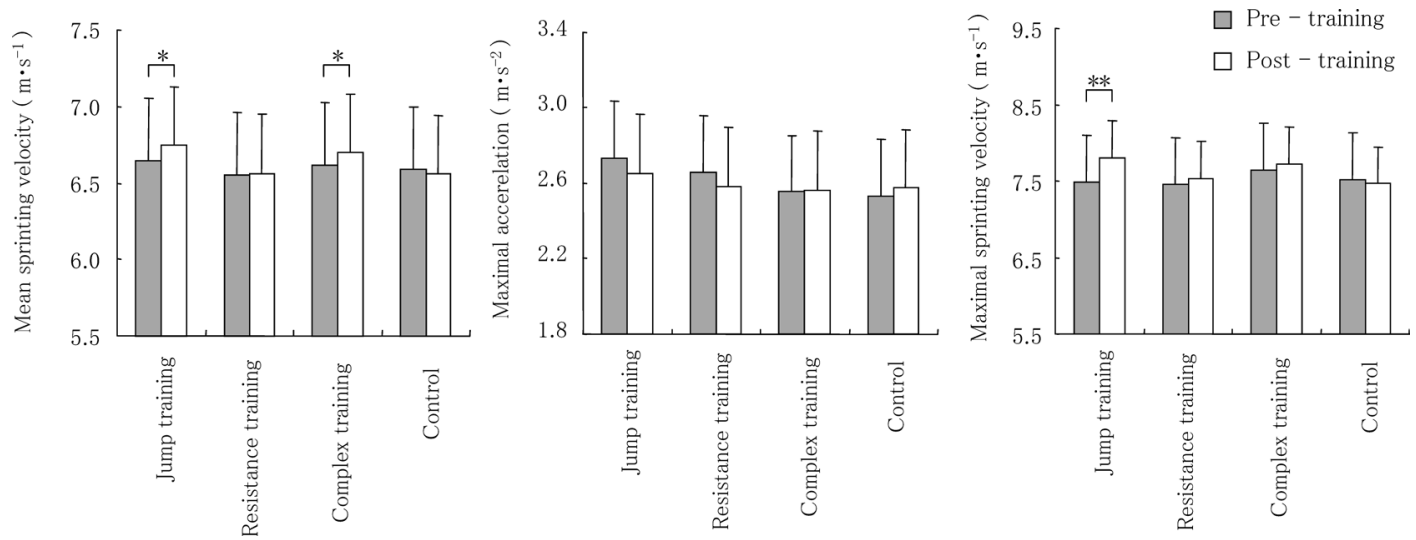

Fig. 1 Comparison of $50 \mathrm{~m}$ mean sprinting velocity, maximal accerelation and maximal sprinting velocity in each training group. $* p<0.05, * * p<0.005$
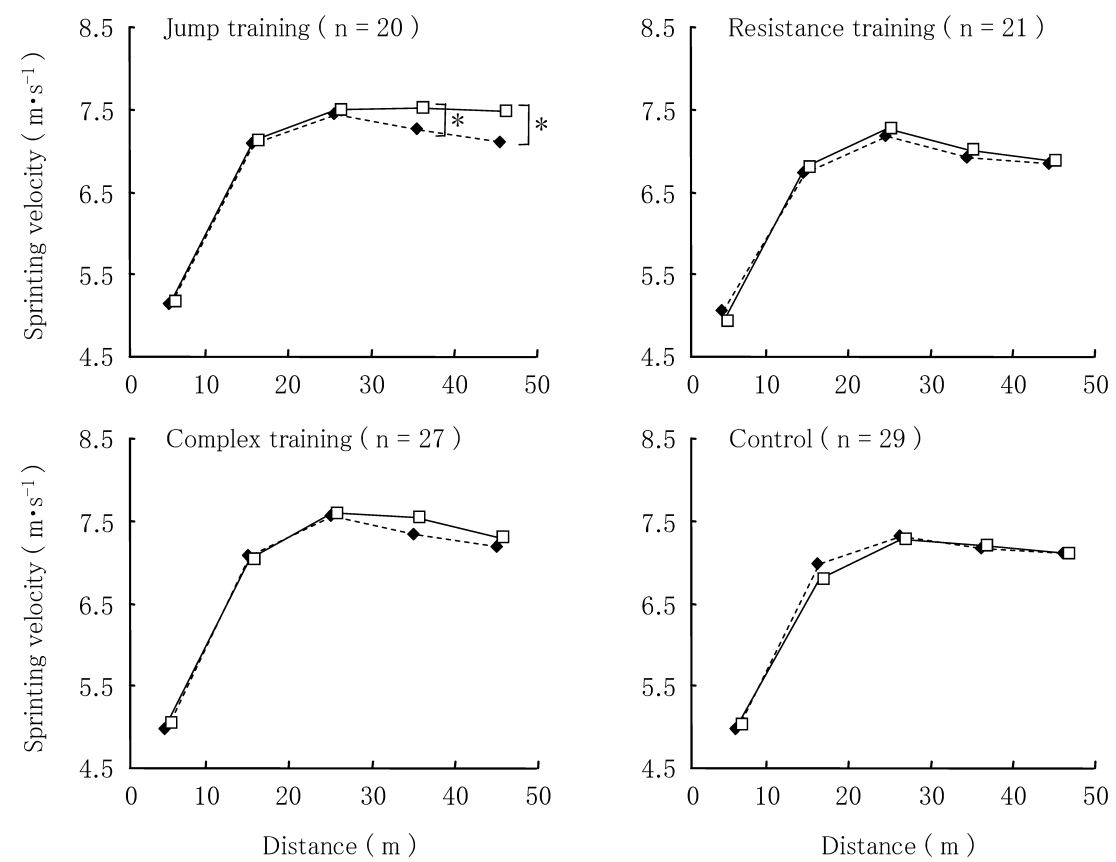

Fig. 2 Changes in sprinting velocity at $10 \mathrm{~m}$ intervals of each training group. The dotted line indicates pre-training, and the solid line indicates post-training. $* p<0.05$

ニング群および複合トレーニング群において有意 な増加を示した。 また, 最大疾走速度は, ジャン プトレーニング群において有意な増加を示した。

一方, 最大加速度は, いずれの群においても有意 な変化を示さなかった。

Fig. 2 は，10m 区間毎の疾走速度をトレーニン グ前後で比較したものである，0-10 m から 20-30 m 区間における疾走速度は, いずれの群においても
有意な変化を示さなかった。一方， $30-40 \mathrm{~m}$ およ び 40-50m 区間における疾走速度は, ジャンプト レーニング群のみが有意な増加を示した。

Fig. 3 は, 両脚同時のジャンプ力とした垂直跳 の跳躍高, 立幅跳の跳躍距離, リバウンドジャン プの跳躍高, 接地時間およびパワーをトレーニン グ前後で比較したものである．垂直跳の跳躍高は 複合トレーニング群において有意な増加を示した。 

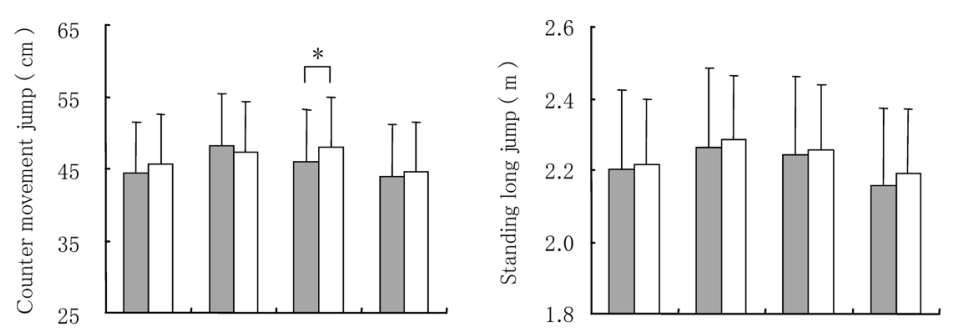

$\square$ Pre - training

$\square$ Post - training
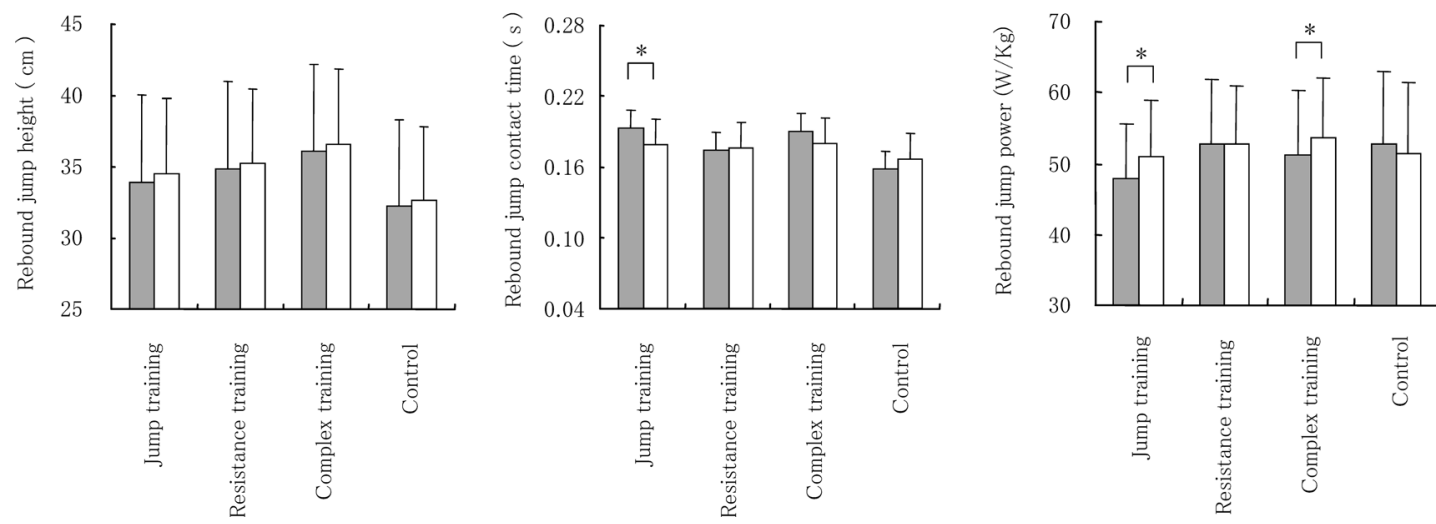

Fig. 3 Comparison of both legs simultaneous jump parameters in each training. * $p<0.05$

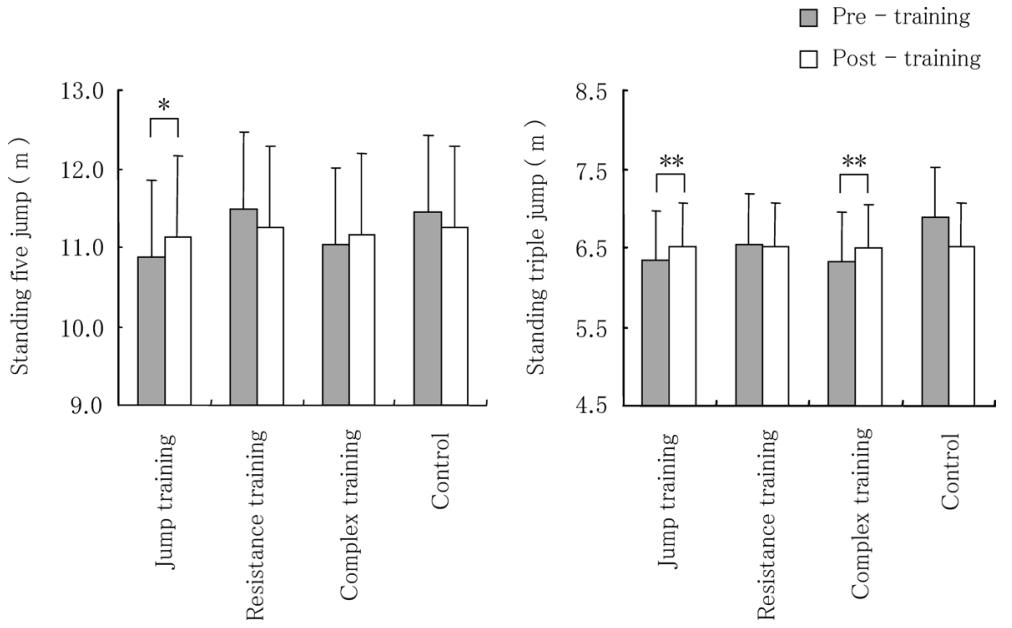

Fig. 4 Comparison of the distance of the standing five jump and the triple jump. $* p<0.05, * * p<0.005$

また，リバウンドジャンプの接地時間は，ジャン プトレーニング群において有意な減少を示した. さらに，リバウンドジャンプのパワーは，ジャン プトレーニング群打よび複合トレーニング群に扔 いて有意な増加を示した。一方, リバウンドジャ ンプの跳躍高および立幅跳の跳躍距離は, いずれ の群も有意な変化を示さなかった。
Fig. 4 は，立五段跳および立三段跳の跳躍距離 をトレーニング前後で比較したものである，立五 段跳は，ジャンプトレーニング群において有意な 増加を示した。 また，立三段跳は，ジャンプト レーニング群および複合トレーニング群において 有意な増加を示した。

Fig. 5 は，脚筋力をトレーニング前後で比較した 


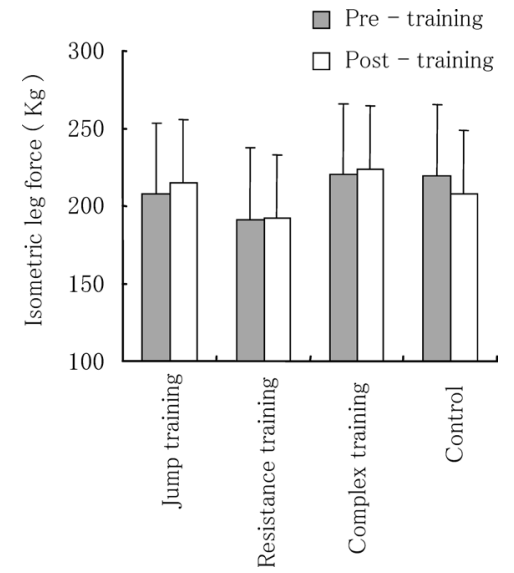

Fig. 5 Comparison of isometric leg force in each training group.

ものである，脚筋力は，いずれの群も有意な変化 を示さなかった。

\section{IV 考 察}

本研究では，思春期後期にある男子生徒を対象 として，体育授業におけるジャンプトレーニング が疾走能力に与える影響について, 各種のジャン プ力や脚筋力の適応を手がかりに検討した。 また, 筋力トレーニング, 複合トレーニングおよびコン トロール条件との比較を行い, ジャンプトレーニ ングの特徵的な効果について明らかにしょうとし た。

加齢に伴う疾走能力の発達は, 下肢長の増加に 伴って歩幅が増加する形態的な発達と, 下肢長が 増加しても同じ歩数を維持し, 下肢長の増加によ る身体質量と重量負荷の増大に対してさらに歩幅 が増加する機能的な発達の両要素にあると考えら れている（斉藤・伊藤, 1995）。ところが, 思春期 後期の年代では, 形態的な発達速度が低下するた めに疾走能力が停滞を迎えることから, 思春期後 期にある男子生徒の疾走能力を改善しょうとする ならば，脚の機能的な発達を目指す必要がある. 脚の機能的な発達に着目した場合, ジャンプパ フォーマンス (跳躍高, 発揮パワー, stiffnessな ど）と疾走能力との間に関係が認められることや (Mero et al., 1981; Bosco et al., 1983; Chelly and Denis,
2001; Bret et al., 2002; 岩竹ほか, 2001, 2002），地面に 対して短時間に大きな加速力を発揮することが高 い疾走速度の獲得に必要であることから（福田・ 伊藤, 2004), 脚が短時間で大きな力を発揮する能 力を高めるジャンプトレーニングは, 疾走能力の 改善に有効と考えられる.

本研究に打ける各トレーニングが疾走能力に与 える影響をみると, $50 \mathrm{~m}$ 平均疾走速度は, ジャン プトレーニング群および複合トレーニング群にお いて有意な増加を示した (Fig. 1). このことから， 本研究で実施したジャンプトレーニングおよび複 合トレーニングにより, $50 \mathrm{~m}$ 平均疾走速度が向上 することが明らかになった。本研究の結果は, こ れまで思春期前期において認められてきた，疾走 能力を改善するジャンプトレーニング (Kotzamanidis, 2006) や複合トレーニング (Ingle et al., 2006) が，思春期後期にある男子生徒を対象に したトレーニングとしても有効なことを示すもの である。

さらに，本研究のジャンプトレーニング群では， 最大疾走速度と 30-40m および 40-50m 区間にお ける疾走速度が有意な増加を示した（Fig. 1 およ び Fig. 2)。このことから, 本研究で実施したジャ ンプトレーニングにより，等速疾走局面における 疾走速度が向上することが明らかになった。短距 離走におけるピッチとストライドは，思春期前期 にある児童（加藤ほか, 2000）においても，世界一 流競技者（阿江・鈴木, 1992）においても，疾走直 後の初期加速段階に増加する。しかし，等速疾走 局面ではピッチが減少傾向を，ストライドが増加 傾向を示す。このような疾走パターンを考えると, 本研究のジャンプトレーニング群において等速疾 走局面の疾走能力が改善した理由は, 疾走中に水 平方向への推進力が増大して歩幅が増加する, 脚 の筋機能の改善に起因すると推察される.

Kotzamanidis (2006) の報告に扔いても，思春期 前期にある児童に対してジャンプトレーニングを 行なわせた結果, $30 \mathrm{~m}$ 全力疾走における加速疾走 局面（0-10m 区間）の疾走速度は向上せず，本研 究でも同様の結果が得られた。この理由について Kotzamanidis (2006) は，トレーニングプログラムが 
初期加速段階の疾走速度を高めるのに必要なパ ワーを増大させる内容ではなかったことを挙げて いる。本研究に打けるジャンプトレーニング群お よび複合トレーニング群は, 接地時間の短縮を意 識したジャンプを反復しており, 加速疾走能力を 改善させるために必要な力積を十分に高めるよう な内容ではなかったことが推察される。したがっ て, 加速疾走能力を改善するためのトレーニング については，接地時間の短縮を意識したプログラ ムとは異なる方法を検討していく必要があると考 えられる。

次に，各トレーニングが両脚同時のジャンプ力 に与える影響をみると, リバウンドジャンプのパ ワーはジャンプトレーニング群および複合トレー ニング群において有意な増加を, リバウンドジャ ンプの接地時間はジャンプトレーニング群におい て有意な減少を, 垂直跳の跳躍高は複合トレーニ ング群において有意な増加を示した (Fig. 3). 一方, 各トレーニングが片脚交互のジャンプカに与える 影響をみると，立五段跳の跳躍距離はジャンプト レーニング群において有意な増加を, 立三段跳の 跳躍距離はジャンプトレーニング群および複合卜 レーニング群において有意な増加を示した (Fig. 4). また，各トレーニングが脚筋力に与える影響をみ ると，いずれの群においても有意な変化が認めら れなかった (Fig. 5)。これらのことから, 本研究で 実施したジャンプトレーニングにより，リバウン ドジャンプの接地時間が減少してパワーが向上す ること, 立五段跳および立三段跳の跳躍距離が向 上することが明らかになった。一方, 複合トレー ニングにより, 垂直跳の跳躍高㧍よびリバウンド ジャンプのパワーが向上すること, 立三段跳の跳 躍距離が向上することが明らかになった。

本研究に扔いて, 接地時間の短縮を意識した ジャンプを反復することにより, 筋力や瞬発力の 発達が緩やかになる思春期後期の年代（桜木, 2000）に対しても，脚が短時間で大きな力を発揮 する能力が改善したことは, 特筆すべき事項であ る. 特に, ジャンプトレーニング群において, リ バウンドジャンプの接地時間が有意な減少を示し たことから，立五段跳や立三段跳においても接地
時間が短縮して, 脚が短時間に大きな力を発揮す る能力が改善し, 跳躍距離の向上に影響したと推 察される。また，ジャンプトレーニング群では， 水平方向への移動を伴うジャンプを多く反復した ことで, 複合トレーニング群に比較して立五段跳 や立三段跳の運動学習が促進されたことも推察さ れる。一方，複合トレーニング群では，接地時間 の短縮を意識したジャンプの反復以外に，筋力発 揮時間の長いスクワットなどの脚の屈伸運動を反 復したことから，垂直跳のように踏切時間の長い ジャンプ力が向上する傾向にあったと推察される. しかし，筋力トレーニング群では，ジャンプトレー ニングを実施しなかったことからジャンプ力の変 化は認められなかったが，脚筋力にも有意な向上 が認められなかった。 そのため, 筋力トレーニン グの効果が十分に得られていなかったものと考え られる。 また，筋力トレーニングの内容が上肢や 体幹部へ負荷が掛かっていなかったのに対して, 脚筋力の評価方法が上肢や体幹部の筋力を含んで いたため，脚筋力が正確に反映されていなかった ことも考えられる. 特別な機器を用いない筋力卜 レーニングを実施する場合の負荷設定や適切な脚 筋力の評価方法については，今後検討していく必 要があるといえよう.

本研究の結果から，ジャンプトレーニングの特 徵的な効果として, (1) $50 \mathrm{~m}$ 平均疾走速度が向上 すること，(2) 最大疾走速度と等速疾走局面にお ける疾走速度が向上すること，(3)リバウンド ジャンプの接地時間が短縮してパワーが向上する こと, (4) 立五段跳抢よび立三段跳の跳躍距離が 向上すること，が明らかにされた．先行研究にお いて, 疾走能力を改善するためのジャンプトレー ニングには，疾走運動に類似した力の発揮時間や 特異的動作を含んでいることが重要とされている (Delecluse, 1997). 特に, 短い接地時間で水平方向 への大きな推進力を発生するバウンディングは, 短距離走の力発揮パターンと類似することから, 疾走能力を改善する特異的なトレーニング手段に なると説明されている (Mero and Komi, 1994)。本研 究においても，バウンディングを含めた水平方向 へのジャンプトレーニングを実施することで疾走 
速度が向上しており, 先行研究を裏付ける結果で あった，そして，本研究の結果を総合的に考える と, ジャンプトレーニングにより, 両脚同時抢よ び片脚交互のジャンプ力が向上し, 疾走動作に類 似した動きの中で短時間に大きな力を発揮する脚 の筋機能が高まることで，等速疾走局面における 推進力が増大して歩幅の増加に影響を与え, $50 \mathrm{~m}$ の疾走能力が改善したものと推察される。これら の知見は, 思春期後期にある男子生徒の疾走能力 を改善するための体育授業を計画するうえで，有 益な情報になるものと考えられる, 今後は, 思春 期後期にある女子生徒についても, ジャンプト レーニングが疾走能力に与える効果について検討 し，具体的なトレーニングプログラムを構築する 必要があるといえよう。

\section{$V$ 要約}

本研究では, 思春期後期にある男子生徒を対象 として，体育授業中にジャンプトレーニング (ハードルジャンプ，スキップおよびバウンディン グ), 筋力トレーニング (レッグランジ, シング ル・レッグ・スクワットおよびスクワット）抢よ び複合トレーニングを週 1 回の頻度で 8 週間実施 し, 各トレーニングが $50 \mathrm{~m}$ 疾走能力に与える影響 を各種のジャンプ力や脚筋力の適応から検討する ことにした。

疾走能力に関する項目では, ジャンプトレーニ ング群において $50 \mathrm{~m}$ 平均疾走速度, 最大疾走速 度，30-40m 抢よび 40-50 $\mathrm{m}$ 区間における疾走速度 が有意に向上した。また, 複合トレーニング群に おいて $50 \mathrm{~m}$ 平均疾走速度が有意に向上した。ジャ ンプ力に関する項目では, ジャンプトレーニング 群に扔いて, リバウンドジャンプの接地時間が有 意に短縮してパワーが有意に向上し, 立五段跳打 よび立三段跳の跳躍距離が有意に向上した。また, 複合トレーニングにおいてリバウンドジャンプの パワー, 垂直跳の跳躍高扔よび立三段跳の跳躍距 離が有意に向上した。脚筋力に関する項目では, いずれの群も有意な変化を示さなかった。

本研究の結果は, 筋力や瞬発力の発達が緩やか
になる思春期後期の年代に対しても，体育授業に おいてジャンプを反復するトレーニングを実施す ることで, 疾走動作に類似した動きの中で脚が短 時間に大きな力を発揮する能力が高まり, 疾走能 力が改善することを示唆するものである.

\section{付 記}

本研究は, 財団法人上月スポーツ・教育財団に よる第 4 回スポーツ研究助成事業の配分を受けて 行なわれた。

\section{文献}

阿江通良・鈴木美佐緒（1992）世界一流スプリンターの レースパターン. Jpn. J. Sports Sci., 11: 609-614.

Bret, C., Rahmani, A., Dufour, A. B., Messonnier, L. and Lacour, J. R. (2002) Leg strength and stiffness as ability factors in 100m sprint running. J. Sports Med. Phys. Fitness, 42: 274-281.

Bobbert, M. F. (1990) Drop jumping as a training method for jumping ability. Sports Med., 9: 7-22.

Bosco, C., Luhtanen, P. and Komi, P. V. (1983) A simple method for measurement of mechanical power in jumping. Eur. J. Appl. Physiol., 50: 273-282.

Chelly, S. M. and Denis, C. (2001) Leg power and hopping stiffness: relationship with sprint running performance. Med. Sci. Sports Exerc., 33: 326-333.

Chimera, N. J., Swanik, K. A., Swanik, C. B., and Straub, S. J. (2004) Effects of plyometric training on muscle-activation strategies and performance in female athletes. J. Athl. Train., 39: 24-31.

Delecluse, C. (1997) Influence of strength training on sprint running performance. Sports Med., 24: 147-156.

福田厚治・伊藤 章 (2004) 最高疾走速度と接地期の身 体重心の水平速度の減速・加速：接地による減速を減 らすことで最高疾走速度は高められるか. 体育学研究, 49: 29-39

Hewett, T. E., Stroupe, A. L., Nance, T. A., and Noyes, F. R. (1995) Plyometric training in female athletes. Am. J. Sports Med., 24: 765-773.

池田祐介・淵本隆文（2005）ダブルレッグホップのト レーニングにともなう下肢関節のモーメントとパワー の変化. 体育学研究, 50:1-11. 
Ingle, L., Sleap, M. and Tolfrey, K. (2006) The effect of a complex training and detraining programme on selected strength and power variables in early pubertal boys. J. Sports Sci. 24: 987-997.

岩竹 淳 - 永澤 健 - 伊澤英紀 - 中村夏実 - 小田宏 行・鈴木朋美・飯田晴子（2001）疾走直後の血中乳酸 濃度によるコンディション評価. トレーニング科学, 13: $13-20$.

岩竹 淳 - 鈴木朋美 - 中村夏実 - 小田宏行 - 永澤 健・岩壁達男（2002）陸上競技選手のリバウンドジャ ンプにおける発揮パワーとスプリントパフォーマンス との関係. 体育学研究, 47: 253-261.

加藤謙一 ・関戸康雄 - 岡崎秀充 (2000) 小学 6 年生の体 育授業における疾走能力の練習効果. 体育学研究, 45 : 530-542.

加藤謙一 (2004) 走能力の発育発達. 金子公宥・福永哲 夫編 バイオメカニクス一身体運動の科学的基礎一. 杏林書院：東京, pp. 178-185.

Kotzamanidis, C. (2006) Effect of plyometric training on running performance and vertical jumping in prepubertal boys. J. Strength Cond. Res. 20: 441-445.

マリーナ・ブシャール：高石昌弘ほか訳（1995）発育・ 成熟・運動. 大修館書店 : 東京, pp. 8-9, 113-114.

Mero, A., Luhtanen, P., Viitasalo, J. T. and Komi, P. V. (1981)
Relationships between the maximal running velocity, muscle fiber characteristics, force production and force relaxation of sprinters. Scand. J. Sports Sci., 3: 16-22.

Mero, A. and Komi, P.V. (1994) EMG, force, and power analysis of sprint-specific strength exercise. J. Appl. Biomech., 10: 1-13.

桜木真智子（2000）運動の発達, 片岡洵子ほか編 身体発 達. ぶんしん出版 : 東京, pp. 194-210.

斉藤昌久・伊藤 章（1995）2 歳児から世界一流短距離 選手までの疾走能力の変化. 体育学研究, 40: 104-111. Wilson, G. J., Newton, R. U., Murphy, A. J. and Humphries, B. J. (1993) The optimal training load for the development of dynamic athletic performance. Med. Sci. Sports Exerc., 25: 1279-1286.

Young, W., McLean, B. and Ardagna, J. (1995) Relationship between strength qualities and sprinting performance. J. Sports Med. Phys. Fitness, 35: 13-19.

Young, W. B., Wilson, G. J. and Byrne, C. (1999) A comparison of drop jump training method: Effects on leg extensor strength qualities. Int. J. Sports Med., 20: 295-303.

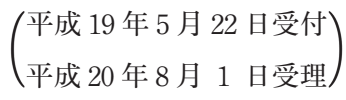

